\title{
Heterozygosity for a Defective Gene for CC Chemokine Receptor 5 Is Not the Sole Determinant for the Immunologic and Virologic Phenotype of HIV-infected Long-Term Nonprogressors
}

\author{
Oren J. Cohen, ${ }^{*}$ Mauro Vaccarezza, ${ }^{*}$ Gordon K. Lam, ${ }^{\star}$ Barbara F. Baird, ${ }^{\star}$ Kathryn Wildt, ${ }^{*}$ Philip M. Murphy, ${ }^{\ddagger}$ \\ Peter A. Zimmerman, ${ }^{\S}$ Thomas B. Nutman, ${ }^{\S}$ Cecil H. Fox, "Shelley Hoover, " Joseph Adelsberger," Michael Baseler," \\ James Arthos, ${ }^{*}$ Richard T. Davey, Jr., ${ }^{*}$ Robin L. Dewar, ${ }^{* \star}$ Julia Metcalf, ${ }^{*}$ Douglas J. Schwartzentruber, ${ }^{\ddagger \ddagger}$ Jan M. Orenstein, $\$ \$$

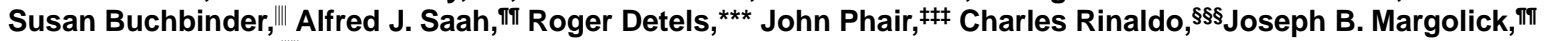 \\ Giuseppe Pantaleo, \\ $*$ Laboratory of Immunoregulation, ${ }^{\ddagger}$ Laboratory of Host Defenses, and the ${ }^{\S}$ Laboratory of Parasitic Diseases, National Institute of Allergy \\ and Infectious Diseases, Bethesda, Maryland 20892; "Molecular Histology, Inc., Gaithersburg, Maryland 20879; "Frederick Cancer \\ Research and Development Center, Science Application International Corporation, National Cancer Institute, Frederick, Maryland 21702; \\ **Laboratory of Virus Isolation and Serology, National Cancer Institute-Frederick Cancer Research and Development Center, Frederick, \\ Maryland 21701; ${ }^{\ddagger}$ Surgery Branch, National Cancer Institute, Bethesda, Maryland 20892; ${ }^{\S}$ Department of Pathology, George \\ Washington University Medical Center, Washington, DC 20037; "llinical Studies Section, San Francisco AIDS Office, San Francisco, \\ California 94102; "III School of Hygiene and Public Health, Johns Hopkins University, Baltimore, Maryland 21205; ***Department of \\ Epidemiology, UCLA School of Public Health, Los Angeles, California 90095; $¥ ¥$ Comprehensive AIDS Center, Northwestern University \\ School of Medicine, Chicago, Illinois 60611; ${ }^{\S \S}$ Department of Pathology, University of Pittsburgh School of Public Health, Pittsburgh,

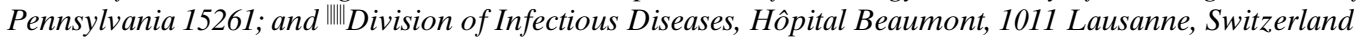

\begin{abstract}
HIV-1-infected long-term nonprogressors are a heterogeneous group of individuals with regard to immunologic and virologic markers of $\mathrm{HIV}-1$ disease. $\mathrm{CC}$ chemokine receptor 5 (CCR5) has recently been identified as an important coreceptor for HIV-1 entry into CD4 + T cells. A mutant allele of CCR5 confers a high degree of resistance to HIV-1 infection in homozygous individuals and partial protection against HIV disease progression in heterozygotes. The frequency of CCR5 heterozygotes is increased among HIV-1infected long-term nonprogressors compared with progressors; however, the host defense mechanisms responsible for nonprogression in CCR5 heterozygotes are unknown. We hypothesized that nonprogressors who were heterozygous for the mutant CCR5 gene might define a subgroup of nonprogressors with higher CD4+ T cell counts and lower viral load compared with CCR5 wild-type nonprogressors. However, in a cohort of $33 \mathrm{HIV}$-1-infected long-term nonprogressors, those who were heterozygous for the mutant CCR5 gene were indistinguishable from CCR5 wild-type nonprogressors with regard to all measured immunologic and virologic parameters. Although epidemiologic data support a role for the mutant CCR5 allele in the determination of the state of long-term nonprogression in some HIV-1infected individuals, it is not the only determinant. Furthermore, long-term nonprogressors with the wild-type CCR5 genotype are indistinguishable from heterozygotes from an
\end{abstract}

Address correspondence to Oren J. Cohen, M.D., National Institute of Allergy and Infectious Diseases, Laboratory of Immunoregulation, 10 Center Drive MSC 1876, Building 10, Room 11B13, Bethesda, MD 20892-1876. Phone: 301-496-5508; FAX: 301-402-0070; E-mail: ocohen@ nih.gov

Received for publication 26 March 1997 and accepted in revised form 14 July 1997.

The Journal of Clinical Investigation

Volume 100, Number 6, September 1997, 1581-1589

http://www.jci.org immunologic and virologic standpoint. (J. Clin. Invest. 1997. 100:1581-1589.) Key words: HIV-1 • disease progression - CC chemokine receptor 5 - polymorphism • lymph nodes

\section{Introduction}

The natural history of infection with HIV is highly variable and dependent on multiple viral and host factors $(1,2)$. A small percentage of individuals infected with HIV-1 for long periods of time remain asymptomatic and free from progressive immunodeficiency; these individuals are referred to as long-term nonprogressors (3-7). Compared with individuals with progressive HIV-1 disease, long-term nonprogressors typically have lower viral load, more vigorous HIV-1-specific cell-mediated immune responses, and higher titers of HIV-1neutralizing antibodies (3-8). In addition, lymph nodes from long-term nonprogressors do not exhibit the typical architectural disruptions associated with progressive HIV-1 disease (6). Although evidence of viral attenuation is present only in the minority of nonprogressors (9-12), a high degree of viral diversity is present, apparently driven by vigorous cell-mediated immune responses $(13,14)$. Despite these clear-cut differences compared with progressors, considerable variability is observed in the aforementioned parameters among long-term nonprogressors, and it is clear that they constitute a heterogeneous group.

CC chemokine receptor 5 (CCR5), ${ }^{1}$ a seven-transmembrane $\mathrm{G}$ protein-coupled cellular receptor, has recently been shown to be a coreceptor for macrophage (M)-tropic or nonsyncytium-inducing (NSI) strains of HIV-1 (15-19), which are the predominant transmitting strains of the virus $(20,21)$. Natural ligands for CCR5 include macrophage inflammatory pro-

1. Abbreviations used in this paper: bDNA, branched-chain DNA; CCR5, CC chemokine receptor 5; CI, confidence interval; LNMC, lymph node mononuclear cells; $\mathrm{M}$, macrophage; MIP, macrophage inflammatory protein; NSI, non-syncytium-inducing; RANTES, regulated-upon-activation, normal $\mathrm{T}$ expressed and secreted; SI, syncytium-inducing. 
tein (MIP)- $1 \alpha$, MIP-1 $\beta$, and RANTES (regulated-upon-activation, normal $\mathrm{T}$ expressed and secreted), which have been shown to inhibit HIV replication in CD4+ T cells and are secreted by a variety of cell types (22), including CD8+ T cells (23). Studies of individuals who have been multiply-exposed to HIV-1 yet remain uninfected (exposed-uninfected), suggested that CD8 + T cells from these individuals secrete high levels of MIP-1 $\alpha$, MIP-1 $\beta$, and RANTES (24). However, a role for CCR5 in the pathogenesis of HIV-1 disease was demonstrated when two exposed-uninfected individuals were found to be homozygous for a 32-bp deletion within the CCR5 open reading frame (CCR5- $\Delta 32)$, which yields a truncated, nonfunctional protein (25).

Several lines of evidence have suggested that homozygosity for the inactivating mutation within CCR5 confers resistance to HIV-1 infection. In this regard, molecular epidemiologic studies have identified very few CCR5- $\Delta 32$ homozygotes among thousands of HIV-1-infected individuals, despite the fact that homozygosity confers no overt deleterious phenotype and is found in $\sim 1 \%$ of the HIV-1-uninfected Caucasian population (26-32). In addition, the CCR5- $\Delta 32$ homozygous genotype is enriched in populations of exposed-uninfected individuals (27-29). Finally, PBMC from CCR5- 32 homozygotes fail to support fusion with M-tropic HIV-1 envelope-expressing cells, and are resistant to infection with M-tropic strains of HIV-1 $(25,26)$.

Several groups have shown that cohorts of long-term nonprogressors are enriched for individuals heterozygous for the mutant CCR5 gene, and that heterozygous seroconverters experience a slower rate of disease progression compared with CCR5 wild-type seroconverters $(27,29,33,34)$. These findings suggest that while CCR5- $\Delta 32$ homozygotes may be protected from HIV-1 infection, heterozygotes may be partially protected against disease progression. The preliminary observation that CD4+ T cells from CCR5- $\Delta 32$ heterozygotes support viral entry and replication with decreased efficiency compared with cells from CCR5 wild-type individuals suggested that lower viral load and slower loss of CD4+ T cells might be found in these compared with CCR5 wild-type individuals (25). Therefore, we examined immunologic and virologic parameters of HIV-1 disease progression in a cohort of 33 long-term nonprogressors in order to determine whether CCR5- $\Delta 32$ heterozygotes constitute a distinct subgroup of nonprogressors with regard to $\mathrm{CD} 4+\mathrm{T}$ cell counts and viral loads compared with CCR5 wild-type nonprogressors.

\section{Methods}

Patients. 33 individuals with long-term nonprogressive HIV-1 infection were studied at the National Institutes of Health Clinical Center. Criteria for the definition of long-term nonprogression included documented HIV-1 seropositivity for longer than $7 \mathrm{yr}$, stable CD4+ T cell counts $>600 / \mathrm{mm}^{3}$, absence of symptoms, and no history of antiretroviral treatment (6). Immunologic and virologic characteristics of 9 of the 33 subjects have been reported previously (6). The mean age of the subjects was 42.2 yr. 31 subjects $(93.9 \%)$ were males who had contracted HIV-1 infection through homosexual contact. There were 2 females among the nonprogressors: one had contracted HIV-1 infection through heterosexual contact, and one had no known risk factor for HIV infection. 29 (87.9\%) of the subjects were Caucasian, and 4 $(12.1 \%)$ were African-American. The mean duration of documented HIV-1 seropositivity was $11.0 \mathrm{yr}$; the mean CD4+ T cell count was
897 cells $/ \mathrm{mm}^{3}$; and the geometric mean level of plasma viremia was 2,065 HIV-1 RNA copies/ml of plasma (see Table I).

Lymph node biopsies. Excisional lymph node biopsies were performed on 26 of the 33 long-term nonprogressors according to a protocol approved by the Institutional Review Board of the National Institute of Allergy and Infectious Diseases.

Genotypic analysis of CCR5. Genotypic analysis of CCR5 alleles was performed as described, and the results were reported previously in preliminary form (29). The full-length open reading frame of CCR5 was amplified from genomic DNA (sense primer, 5' CCCAAGCTTACTCTCCCCGGGTGGAACAAGATG 3'; antisense primer, 5' GGTCTAGAGTCACCAGCCCACTTGAGTCCGTG $3^{\prime}$ ) by PCR. CCR5 PCR products were subjected directly to BglII digestion, and the fragments were visualized after electrophoresis with ethidium bromide staining. A BgIII restriction site is located upstream of the 32-bp deletion site in the CCR5 gene such that the $3^{\prime}$ half of BglII-digested CCR5 yields a 582-bp product in wild-type homozygotes, a 582- and a 550-bp product in CCR5- $\Delta 32$ heterozygotes, and only a 550-bp product in CCR5- $\Delta 32$ homozygotes.

Analysis of surface expression of CCR5. PBMC were stained in a solution of $2 \%$ BSA in Dulbecco's phosphate-buffered saline (dPBS) containing $0.1 \%$ azide with $10 \mu \mathrm{g} / \mathrm{ml}$ anti-CCR5 (clone 2D7-13; a generous gift from Dr. Charles Mackay, Leukocite, Inc., Boston, MA), $10 \mu \mathrm{g} / \mathrm{ml}$ anti-CCR3 (clone 7B11; also a gift from Dr. Mackay), $8 \mu \mathrm{g} / \mathrm{ml}$ anti-CXCR4 (clone 12G5; a generous gift from Dr. James Hoxie, University of Pennsylvania, Philadelphia, PA), or an isotypematched control antibody for $30 \mathrm{~min}$ at $4^{\circ} \mathrm{C}$. Cells were then washed in $2 \% \mathrm{BSA} / \mathrm{dPBS}$, resuspended, and stained with an FITC-conjugated goat anti-mouse $\mathrm{F}\left(\mathrm{ab}^{\prime}\right)_{2}$ antibody at 1:100 final dilution for 15 min at $4^{\circ} \mathrm{C}$. Cells were washed again in $2 \% \mathrm{BSA} / \mathrm{dPBS}$ and incubated with a blocking solution of $1 \mu \mathrm{g} / \mathrm{ml}$ purified mouse Ig (Sigma Chemical Co., St. Louis, MO) for $10 \mathrm{~min}$ at $4^{\circ} \mathrm{C}$. After another wash with $2 \% \mathrm{BSA} / \mathrm{dPBS}$, cells were stained with phycoerythrin-conjugated anti-CD4 antibody (Becton Dickinson, San Jose, CA) for $15 \mathrm{~min}$ at $4^{\circ} \mathrm{C}$. Cells were then washed twice with $2 \% \mathrm{BSA} / \mathrm{dPBS}$, resuspended in $0.3 \mathrm{ml}$ of $2 \% \mathrm{BSA} / \mathrm{dPBS}$, and analyzed with a flow cytometer (model XL; Coulter Corp., Miami, FL). Forward and orthogonal light scatter gates were drawn to include lymphocytes and monocytes. These gated events were further analyzed for the presence of chemokine receptors CCR5, CCR3, or CXCR4 on CD4+ cells.

Analysis of in vitro responses of PBMC to various stimuli. Fresh PBMC $\left(10^{5}\right.$ cells in $\left.200 \mu \mathrm{l}\right)$ were placed in 96-well round-bottomed microtiter plates. The culture medium consisted of RPMI 1640 with $15 \%$ human AB serum. Stimuli included PHA $2 \mu \mathrm{g} / \mathrm{ml}$ (Wellcome Industries, Beckenham, UK), alloantigen (50,000 irradiated allogeneic PBMC), and tetanus toxoid $5 \mu \mathrm{g} / \mathrm{ml}$ (Connaught Laboratories, Swiftwater, PA). Proliferative responses were measured by incorporation of $\left[{ }^{3} \mathrm{H}\right]$ thymidine (New England Nuclear, Boston, MA) over a 4-h pulse with $0.44 \mu \mathrm{Ci}$ of $\left[{ }^{3} \mathrm{H}\right]$ thymidine. Responses to PHA were measured on day 3 of culture, to alloantigens on day 5 , and to tetanus toxoid on day 6 . The stimulation index was calculated as the counts per minute (cpm) for each stimulus minus the background cpm (unstimulated cells), divided by the background $\mathrm{cpm}$. A stimulation index $>5$ was considered a positive response.

Determination of plasma viremia by the branched-chain DNA (bDNA) assay. HIV-1 RNA was quantitated in plasma using the Quantiplex ${ }^{\circledR}$ bDNA assay kit according to the manufacturer's instructions (Chiron Corporation, Emeryville, CA). The concentration of RNA in each specimen is expressed as HIV-1 RNA copies per milliliter, determined from a standard curve using a DNA plasmid at four concentrations. The dynamic range of the assay is 500-800,000 RNA copies $/ \mathrm{ml}$ of plasma, and the sensitivity is $500 \mathrm{HIV}-1$ RNA copies $/ \mathrm{ml}$. Measurements $<500 \mathrm{HIV}-1$ RNA copies/ml were considered equal to $500 \mathrm{HIV}-1$ copies $/ \mathrm{ml}$ for the purposes of calculations for statistical analysis.

Analysis of HIV-1 DNA in PBMC and lymph node mononuclear cells $(L N M C)$ by PCR. Proviral HIV-1 DNA was quantitated by a semiquantitative PCR assay (35) with a primer pair (SK145/101) spe- 
cific for the gag gene segment. 32 PBMC specimens and 24 LNMC specimens were available for analysis. Results are expressed as HIV-1 DNA copies per million cells.

Analysis of HIV-1 replication in LNMC by reverse transcription$P C R$. Total RNA was extracted from LNMC from 18 nonprogressors, and $2 \mu \mathrm{g}$ was reverse-transcribed with random hexamers as described previously (36). One-tenth of each reverse transcription was amplified with a common sense primer (5' GACTCATCAAGCTTCTCTATCAAA $3^{\prime}$ ) corresponding to a sequence within the first tat/rev exon and an antisense primer which detects either unspliced plus single-spliced HIV-1 RNA (complementary to a sequence within env: 5' CTCATTGCCACTGTCTTCTGCTCT 3') or multiplyspliced HIV-1 RNA (complementary to a sequence within the second tat/rev exon: 5' TCTCAAGCGGTGGTAGCTGA 3') (36). Positive controls for the detection of unspliced plus single-spliced HIV-1 RNA were serial dilutions of a plasmid cDNA construct containing HIV-1 exons 1 and 4E; for the detection of multiply-spliced HIV-1 RNA, serial dilutions of a plasmid construct containing HIV-1 exons 1,5 , and 7 served as positive controls (37). PhosphorImager analysis was used for signal quantitation.

To normalize for RNA input, 1/25 of each reverse transcription was amplified with a primer pair specific for human $\mathrm{T}$ cell receptor C $\alpha$ mRNA (36). Quantitation of HIV-1 RNA was accomplished by normalization of the HIV-1 amplification signal to the $\mathrm{C} \alpha$ signal and interpolation into the control cDNA serial dilution curve.

In situ hybridization, and immunohistochemical and morphometric analysis of lymphoid tissue. In situ hybridization was performed with a mixture of ${ }^{35} \mathrm{~S}$-radiolabeled RNA probes synthesized from five DNA templates that cumulatively represent $90 \%$ of the HIV-1 genome (38). Immunohistochemical analysis was performed with antiCD21 antibody (DAKO Corp., Carpinteria, CA), which stains follicular dendritic cells in formaldehyde-fixed, paraffin-embedded tissues. Morphometric analysis of the percentage of lymph node area occupied by either CD21 immunostain $(n=24$ of the 26 lymph nodes biopsied) or by HIV-1 RNA detected by in situ hybridization $(n=22)$ was performed with a videoscope camera (CCD 200E; Videoscope International, Reston, VA) and video-planimetry computer software based on National Institutes of Health Image 1.60. Productively infected cells detected by in situ hybridization were counted manually and expressed as the number of productively infected cells per 10 square millimeters of lymph node tissue $(n=25)$.

Determination of serum levels of $\beta$-chemokines. Serum levels of RANTES, MIP- $1 \alpha$, and MIP- $1 \beta$ were determined by enzyme immunoassay according the manufacturer's instructions (R \& D Systems, Inc., Minneapolis, MN). 24 serum samples were available for this analysis.

Statistical analysis. Mean values for measured variables are reported \pm SE. Geometric mean values with $95 \%$ confidence intervals (CI) are reported for logarithmic normally distributed variables (i.e., plasma viremia and HIV-1 proviral burden). Comparisons of the proportion of CCR5- $\Delta 32$ heterozygotes in different groups as well as the proportion of CCR5 wild-type and CCR5- $\Delta 32$ heterozygous individuals whose PBMC responded in vitro to stimuli were made by $\chi^{2}$ analysis.

The molecular epidemiologic analysis of CCR5 genotypes was limited to Caucasians ( $n=29$ among the long-term nonprogressors) because of the very low frequency of the CCR5- $\Delta 32$ allele in nonCaucasian populations $(26,29)$. Comparison of measured variables between the CCR5 wild-type and CCR5- $\Delta 32$ heterozygote group was made by the Mann-Whitney U test: these comparisons were made within the entire cohort of 33 long-term nonprogresssors.

\section{Results}

CCR5 genotype. We have reported recently that among randomly selected North American Caucasian blood donors $(n=$ 387 ), $77.5 \%$ were CCR5 wild-type, $21.7 \%$ were CCR5- $\Delta 32$
Table I. Demographic, Immunologic, and Virologic Characteristics of HIV-infected Long-Term Nonprogressors Stratified by CCR5 Genotype

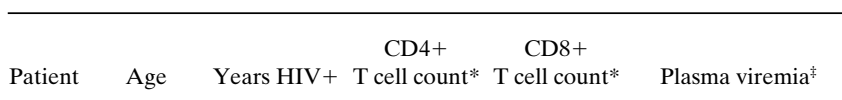

Wild-type CCR5 genotype

$\begin{array}{rrrrrr}001 & 42 & 12 & 810 & 870 & 23000 \\ 002 & 34 & 7 & 992 & 970 & 500 \\ 003 & 45 & 13 & 720 & 2483 & 500 \\ 004 & 41 & 12 & 612 & 1023 & 26000 \\ 005 & 44 & 11 & 972 & 1549 & 500 \\ 006 & 36 & 11 & 636 & 562 & 2708 \\ 007 & 50 & 10 & 766 & 867 & 97000 \\ 008 & 34 & 11 & 1158 & 1129 & 6000 \\ 009 & 43 & 12 & 1053 & 2379 & 500 \\ 010 & 35 & 11 & 890 & 554 & 1000 \\ 011 & 31 & 10 & 653 & 1110 & 1000 \\ 012 & 46 & 10 & 1633 & 1750 & 500 \\ 013 & 45 & 11 & 1238 & 2090 & 500 \\ 014 & 48 & 9 & 1038 & 1291 & 500 \\ 015 & 35 & 12 & 1287 & 1141 & 669 \\ 016 & 39 & 11 & 767 & 2013 & 2000 \\ 017 & 38 & 11 & 637 & 1274 & 4757 \\ 018 & 47 & 8 & 938 & 1488 & 37000 \\ 019 & 55 & 11 & 790 & 909 & 500 \\ 020 & 37 & 11 & 607 & 805 & 14210 \\ 021 & 49 & 11 & 908 & 739 & 500\end{array}$

Mean $41.6 \pm 1.4 \quad 10.7 \pm 0.3 \quad 910 \pm 57 \quad 1286 \pm 124 \quad 2104(992-4460)$

Heterozygous CCR5 genotype

$\begin{array}{lrrrrr}022 & 37 & 12 & 817 & 1010 & 3000 \\ 023 & 50 & 7 & 1043 & 844 & 620 \\ 024 & 33 & 8 & 1066 & 1904 & 3000 \\ 025 & 56 & 18 & 646 & 2926 & 36000 \\ 026 & 35 & 11 & 605 & 549 & 5000 \\ 027 & 42 & 10 & 1026 & 879 & 500 \\ 028 & 36 & 10 & 675 & 527 & 7000 \\ 029 & 42 & 13 & 690 & 858 & 500 \\ 030 & 49 & 9 & 1450 & 673 & 500 \\ 031 & 49 & 13 & 685 & 1178 & 18000 \\ 032 & 43 & 16 & 773 & 855 & 500 \\ 033 & 45 & 12 & 1142 & 961 & 500 \\ \text { Mean } & 43.1 \pm 2.0 & 11.6 \pm 0.9 & 885 \pm 75 & 1097 \pm 196 & 1995(824-4832)\end{array}$

$P$ values (wild-type vs. heterozygous CCR5 genotype)

$$
\begin{array}{lllll}
0.57 & 0.50 & 0.88 & 0.12 & 0.99
\end{array}
$$

*Cells $/ \mathrm{mm}^{3} .{ }^{\ddagger} \mathrm{HIV}-1 \mathrm{RNA}$ copies/ml. Values which were below the sensitivity limit of the assay (i.e., 500 copies $/ \mathrm{ml}$ ) were considered equal to $500 \mathrm{HIV}-1$ RNA copies/ml for the purposes of statistical analysis. Mean values are presented $\pm \mathrm{SE}$, except in the case of plasma viremia, for which the geometric mean values are presented with $95 \%$ CI.

heterozygous, and $0.8 \%$ were CCR5- $\Delta 32$ homozygous (29). Corresponding percentages among HIV-1-infected North American Caucasians $(n=614)$ were $77.4 \%$ CCR5 wild-type, $22.6 \%$ CCR5- $\Delta 32$ heterozygous, and $0 \%$ CCR5- $\Delta 32$ homozygous (29). These results are similar to those reported by other groups $(27,28)$. Among the 29 North American Caucasian 


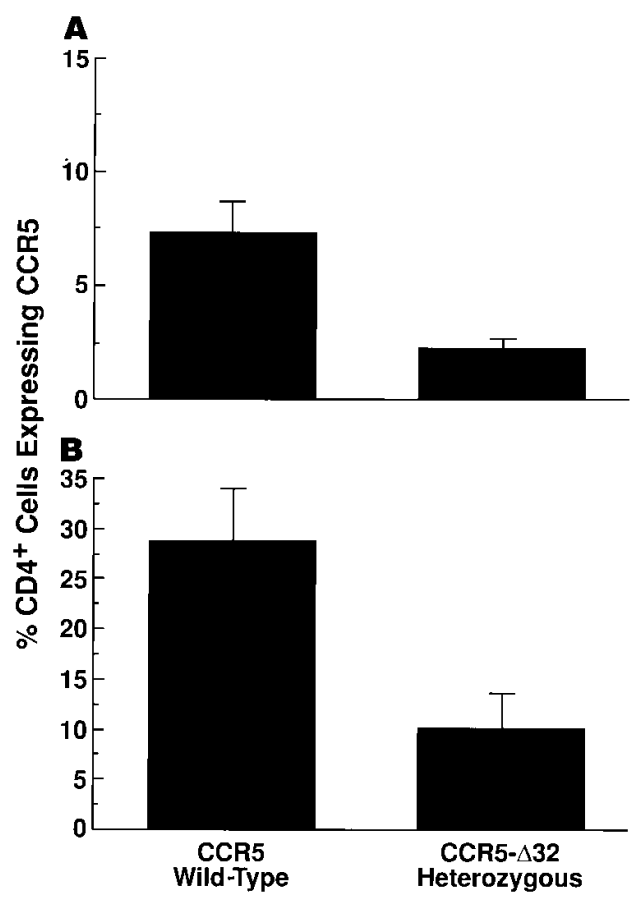

Figure 1. Comparative analysis of CCR5 expression on CD4+ lymphocytes $(A)$ and monocytes $(B)$ from CCR5 wild-type and CCR5$\Delta 32$ heterozygous nonprogressors. A significantly higher percentage of CD4+ lymphocytes and monocytes expressed CCR5 from CCR5 wild-type compared with CCR5- $\Delta 32$ heterozygous nonprogressors $(P=0.04$ and 0.008 , respectively). Mean values \pm SE are shown.

long-term nonprogressors in our cohort, 11 (37.9\%) were CCR5- $\Delta 32$ heterozygotes (29), and this $68 \%$ increase in the expected frequency of CCR5- $\Delta 32$ heterozygotes compared with a broad cross-section of HIV-1-infected individuals $(n=$ $614)$ was statistically significant $(P=0.05)$. There were no significant differences in the mean duration of documented HIV-1 seropositivity or the mean age of the CCR5 wild-type versus heterozygous long-term nonprogressors (Table I).

Cell surface expression of HIV coreceptors. Cell surface expression of CCR5 was significantly lower on CD4+ lymphocytes and monocytes from CCR5- $\Delta 32$ heterozygous long-term nonprogressors compared with CCR5 wild-type nonprogres-
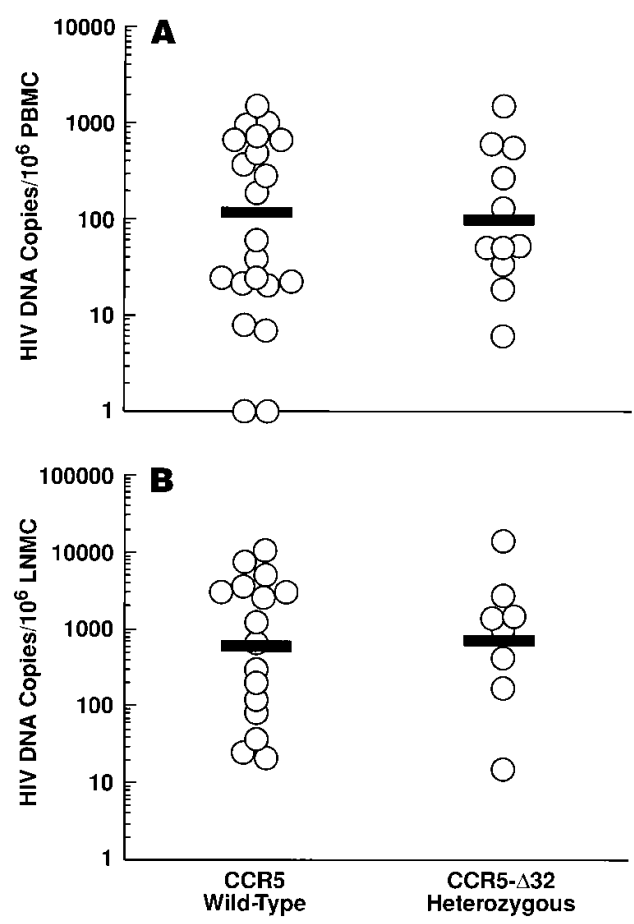

Figure 2. Comparative analysis of HIV-1 proviral burden in PBMC $(A)$ and LNMC $(B)$ from CCR5 wild-type and CCR5- $\Delta 32$ heterozygous long-term nonprogressors. Geometric mean values are indicated by horizontal bars. No significant differences in proviral burden were detected between the two groups of nonprogressors. Consistent with previous reports, the proviral burden in LNMC exceeded that in PBMC approximately sevenfold (35).

sors (Fig. 1). There was no significant difference between CCR5- $\Delta 32$ heterozygotes and CCR5 wild-type nonprogressors in CD4+ lymphocyte and monocyte expression of CXCR4 and CCR3 (data not shown).

Lymphocyte subsets. The mean CD4+ and CD8+ T cell counts were indistinguishable when CCR5 wild-type and heterozygous long-term nonprogressors were compared (Table I).

In vitro responses of PBMC to stimuli. PBMC from all of the long-term nonprogressors responded in vitro to PHA and to alloantigen (data not shown). PBMC from 10 of 21 (47.6\%) CCR5 wild-type nonprogressors responded in vitro to tetanus

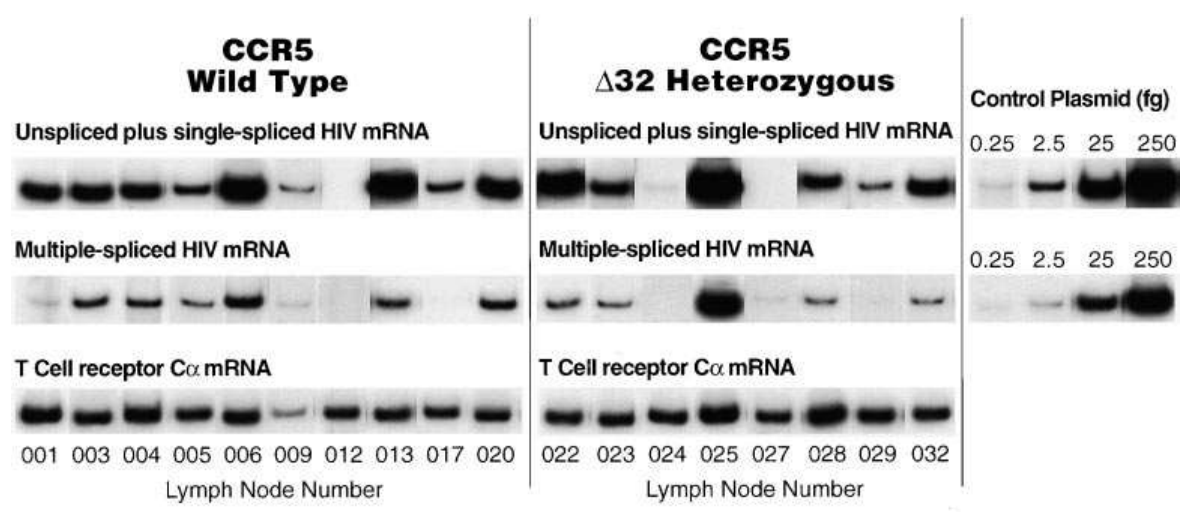

Figure 3. HIV replication detected by PCR in LNMC from CCR5 wild-type $(n=$ 10 , left) and CCR5- $\Delta 32$ heterozygous $(n=$ 8 , middle) long-term nonprogressors. Amplifications of unspliced plus single-spliced HIV RNA are shown (top row), including a dilutional series of a control plasmid (right). Amplifications of the same lymph node samples for multiply-spliced HIV RNA are shown (middle row) along with a dilutional series of a control plasmid (right). The bottom row shows amplifications of the same lymph node samples for $\mathrm{T}$ cell receptor $\mathrm{C} \alpha$ mRNA as a control for the relative total amount of RNA present.

Quantitation of the PCR signals by phosphorImager analysis and normalization according to the C $\alpha$ signal are described in Methods. A high degree of variability in the levels of HIV replication is seen in both CCR5 wild-type and CCR5- $\Delta 32$ heterozygous nonprogressors. 
toxoid compared with 7 of $12(58.3 \%)$ CCR5- $\Delta 32$ heterozygotes $(P>0.5)$.

Plasma viremia. The geometric mean levels of plasma viremia were nearly identical in CCR5 wild-type and heterozygous nonprogressors (Table I). Potential confounding factors were the sensitivity limit of $500 \mathrm{HIV}-1$ RNA copies/ml detected by the bDNA assay, and the lower degree of reproducibility of the assay at low values. However, even if the five measurements of plasma viremia which were $<500$ HIV-1 RNA copies/ml among the CCR5- $\Delta 32$ heterozygotes were considered to equal zero, and the nine values $<500 \mathrm{HIV}-1$ copies/ml among the CCR5 wild-type individuals were considered to equal 500 HIV-1 copies/ml, the mean values remained indistinguishable between the groups $(P=0.41)$.

$H I V-1$ proviral burden. Geometric mean HIV-1 proviral burden in PBMC was 120 (95\% CI 44.7-322) HIV-1 DNA copies/million cells in CCR5 wild-type individuals and 100 (95\% CI 37.0-267) in CCR5- $\Delta 32$ heterozygotes (Fig. 2; $P=$ 0.75). Proviral burden in LNMC was 604 (95\% CI 214-1,705) HIV-1 DNA copies/million cells in CCR5 wild-type individuals and 729 (95\% CI 178-2,980) in CCR5- $\Delta 32$ heterozygotes (Fig. 2; $P=0.99$ ).

$H I V$-1 replication in $L N M C$. Levels of viral replication in PBMC were generally at or below the limit of detectability (data not shown). There was no difference in the level of viral replication in LNMC from CCR5 wild-type nonprogressors compared with CCR5- $\Delta 32$ heterozygotes. The mean level of unspliced plus single-spliced HIV-1 mRNA was $22.9 \pm 6.2 \mathrm{fg}$ per $0.2 \mu \mathrm{g}$ total RNA in LNMC from CCR5 wild-type nonprogressors and 20.4 \pm 8.4 in LNMC from CCR5- $\Delta 32$ heterozygous nonprogressors (Fig. 3; $P=0.37$ ). The mean level of multiply-spliced HIV-1 mRNA in LNMC was $7.8 \pm 1.8 \mathrm{fg}$ per 0.2 $\mu \mathrm{g}$ total RNA from CCR5 wild-type nonprogressors and $10.5 \pm 6.0$ from CCR5- $\Delta 32$ heterozygous nonprogressors (Fig. $3 ; P=0.66)$.

Morphometric analysis of follicular hyperplasia, HIV-1 trapping, and viral expression in lymphoid tissue. The mean percentages of lymph node area occupied by CD21 immunostain (i.e., the relative degree of follicular hyperplasia) and HIV-1 RNA detected by in situ hybridization (i.e., the degree of viral trapping within germinal centers) were comparable between CCR5 wild-type and heterozygous long-term nonprogressors (Table II, and Fig. 4). There was also no significant difference in the mean number of productively infected cells per unit area of lymph node tissue between CCR5 wild-type and heterozygous nonprogressors (Table II).

Serum levels of $\beta$-chemokines. The mean serum levels of RANTES, MIP- $1 \alpha$, and MIP-1 $\beta$ among CCR5 wild-type nonprogressors were $43.9 \pm 4.6 \mathrm{ng} / \mathrm{ml}, 214 \pm 119 \mathrm{pg} / \mathrm{ml}$, and $129 \pm 14$ $\mathrm{pg} / \mathrm{ml}$, respectively. Among CCR5- $\Delta 32$ heterozygous nonprogressors, mean serum levels of RANTES, MIP- $1 \alpha$, and MIP-1 $\beta$ were $40.9 \pm 5.9 \mathrm{ng} / \mathrm{ml}(P=0.93$ compared with CCR5 wild-type nonprogressors $), 42.9 \pm 1.4 \mathrm{pg} / \mathrm{ml}(P=0.09)$, and $110 \pm 6 \mathrm{pg} / \mathrm{ml}$ $(P=0.22)$, respectively (Fig. 5).

\section{Discussion}

Recent studies have clearly demonstrated that individuals who are homozygous for the mutant CCR5 allele, which contains an inactivating 32-bp deletion in the open reading frame, are highly resistant to HIV-1 infection (25-29). Furthermore, the frequency of CCR5- $\Delta 32$ heterozygotes is increased among
Table II. Analysis of Lymph Node Germinal Center Area, Viral Trapping, and Number of Productively Infected Cells

\begin{tabular}{|c|c|c|c|}
\hline Patient & CD21\%* & HIV\%” & $\begin{array}{l}\text { Productively } \\
\text { infected cells }\end{array}$ \\
\hline
\end{tabular}

Wild-type CCR5 genotype

$\begin{array}{lccc}001 & 12.21 & 4.30 & 4.50 \\ 003 & 27.83 & 15.73 & 4.30 \\ 004 & 4.31 & 0.36 & 3.60 \\ 005 & 7.92 & \text { n.d. } & 2.60 \\ 006 & 10.55 & 4.58 & 4.80 \\ 008 & 22.67 & 2.33 & 7.80 \\ 009 & 5.86 & 1.13 & 4.50 \\ 010 & 13.00 & 1.80 & 10.20 \\ 011 & 11.82 & 1.02 & 1.70 \\ 012 & \text { n.d. } & 2.28 & 22.80 \\ 013 & 19.75 & 6.43 & 3.10 \\ 014 & 7.75 & \text { n.d. } & 0.50 \\ 015 & 17.74 & 3.45 & 12.30 \\ 017 & 11.28 & 4.24 & 0.40 \\ 020 & 25.40 & 4.85 & 9.80 \\ 021 & 7.47 & \text { n.d. } & 0.00 \\ \text { Mean } \pm \text { SE } & 13.70 \pm 1.89 & 4.04 \pm 1.09 & 5.81 \pm 1.45\end{array}$

Heterozygous CCR5 genotype

$\begin{array}{lrcc}022 & 18.02 & 9.46 & 1.90 \\ 023 & 5.99 & 1.35 & 8.60 \\ 024 & 8.95 & \text { n.d. } & 1.10 \\ 025 & 12.65 & 5.00 & 8.10 \\ 026 & 8.59 & 13.48 & 1.80 \\ 028 & 10.66 & 3.07 & 9.90 \\ 029 & 5.79 & 1.32 & 3.30 \\ 031 & 10.88 & 5.61 & 9.60 \\ 032 & 9.52 & 0.44 & 0.50 \\ \text { Mean } \pm \text { SE } & 10.12 \pm 1.23 & 4.97 \pm 1.60 & 4.98 \pm 1.32\end{array}$

$P$ values (wild-type vs. heterozygous CCR5 genotype)
0.30
0.61

0.84

Studies done on 25 lymph node specimens available. *Percentage of lymph node area occupied by CD21 immunostain (i.e., relative germinal center area). ${ }^{\ddagger}$ Percentage of lymph node area occupied by HIV RNA detected by in situ hybridization (i.e., degree of viral trapping in germinal centers). ${ }^{8}$ Number of productively infected cells, detected by in situ hybridization per $10 \mathrm{~mm}^{2}$ lymph node. ND, Not done.

HIV-infected long-term nonprogressors $(29,33,34)$ and slow progressors (27). Based upon this observation as well as reported evidence of decreased efficiency of HIV-1 entry and replication in CD4+ $\mathrm{T}$ cells from CCR5- $\Delta 32$ heterozygotes $(25,39)$, we tested the hypothesis that within a group of HIVinfected long-term nonprogressors, CCR5- $\Delta 32$ heterozygotes might harbor lower viral loads and higher CD4+ T cell counts compared with CCR5 wild-type individuals. In agreement with the study by $\mathrm{Wu}$ et al. (39), we found that a significantly lower percentage of CD4+ cells from CCR5- $\Delta 32$ heterozygous nonprogressors coexpressed CCR5 compared with CD4+ cells from CCR5 wild-type nonprogressors. We demonstrate considerable heterogeneity within our cohort of long-term nonprogressors with regard to $\mathrm{CD} 4+$ and $\mathrm{CD} 8+\mathrm{T}$ cell counts, 
plasma viremia, viral burden in peripheral blood and lymph nodes, levels of viral replication in lymph nodes, the degree of follicular hyperplasia and viral trapping in germinal centers, and serum levels of the $\beta$-chemokines. However, heterogeneity with regard to these immunologic and virologic parameters did not diminish when the cohort was stratified according to CCR5 genotype.

It should be noted that although the measured immunologic and virologic parameters were indistinguishable between the two groups of nonprogressors defined by CCR5 genotype, it is possible that the limited sample size prevented the detection of real differences. Another caveat with regard to studies of long-term nonprogressors is the operational definition of nonprogression. We used a clinical definition of nonprogres- sion adapted from the Multicenter AIDS Cohort Study, wherein $<5 \%$ of HIV-infected individuals meet the nonprogressor criteria. Given recent data regarding the strong association between levels of plasma viremia and prognosis in HIV infection (40), we performed a subgroup analysis in this study which included only the 16 CCR5 wild-type and 10 CCR5- $\Delta 32$ heterozygous nonprogressors with levels of plasma viremia $<10,000$ HIV RNA copies/ml. This stringent analysis of immunologic and virologic parameters in long-term nonprogressors stratified by CCR5 genotype yielded results which were virtually identical to the analysis conducted in the entire cohort: CCR5 wild-type and CCR5- $\Delta 32$ heterozygous nonprogressors remained immunologically and virologically indistinguishable.

\section{CD21}

A

Patient \#003
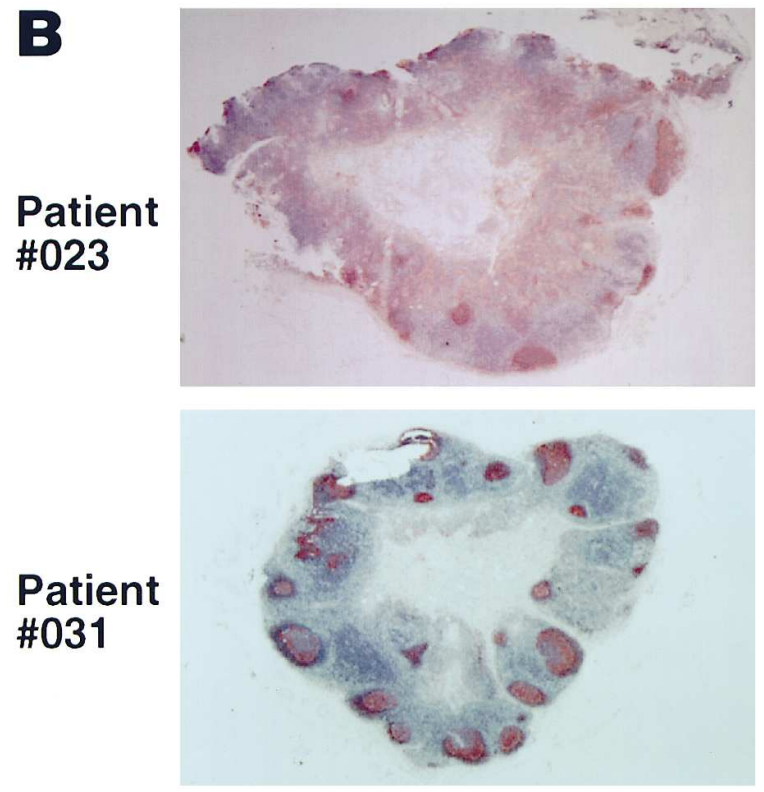

\section{HIV In Situ}
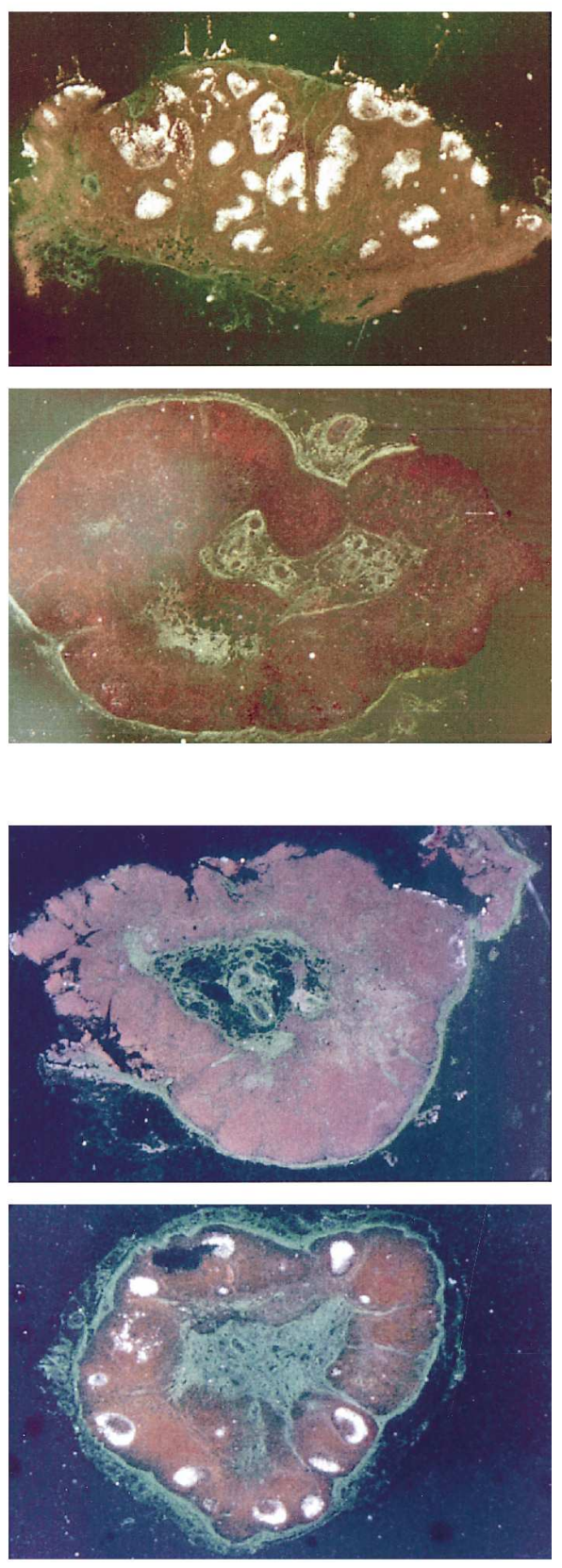

Figure 4. Distribution of HIV-1 RNA in lymph nodes of HIV-infected CCR5 wild-type and CCR5- $\Delta 32$ heterozygous nonprogressors. Photomicrographs $(\times 35)$ of immunohistochemistry for CD21 and in situ hybridization for HIV-1 RNA are shown in representative lymph node sections from CCR5 wildtype $(A)$ and CCR5- $\Delta 32$ heterozygous nonprogressors $(B)$. CD21 staining, highlighting germinal centers, appears red (left column). HIV-1 RNA appears white in the dark-field micrographs (right column). 
The failure of HIV-infected CCR5- $\Delta 32$ heterozygotes to constitute a distinct subgroup of nonprogressors with lower viral load and higher CD4+ T cell counts does not exclude a role for the mutant allele in protecting against disease progression. Epidemiologic data support a partially protective role against disease progression for CCR5- $\Delta 32$ heterozygosity; the frequency of CCR5- $\Delta 32$ heterozygotes was found to be disproportionately high in long-term nonprogressors from our own cohort as well as others $(27,29,33,34)$. Among seroconverters from the Multicenter AIDS Cohort Study, heterozygotes had slower rates of decline in CD4+ T cell counts and lower levels of plasma viremia 9-18 mo after seroconversion compared with CCR5 wild-type individuals (28). Although no delay in progression to AIDS could be detected among heterozygotes in that study, two other studies which combined seroconverters from several cohorts did find that CCR5- $\Delta 32$ heterozygosity correlated with a delay in progression to $\operatorname{AIDS}(27,29)$. Data regarding the lower levels of plasma viremia 9-18 mo after seroconversion in CCR5- $\Delta 32$ heterozygotes (28) are compelling, given the prognostic value of this measurement (40, 41). Therefore, one plausible mechanism for nonprogression with HIV infection may be a lower viral load set-point after acute infection due to reduced availability of functional CCR5 coreceptors in CCR5- $\Delta 32$ heterozygotes.

It is clear that heterozygosity for the mutant CCR5 gene is not the sole or even dominant explanation for nonprogression in HIV disease, since CCR5 wild-type nonprogressors are also able to achieve the same high-CD4+ $\mathrm{T}$ cell count/low-viral load phenotype. In this regard, it is possible that in certain CCR5 wild-type individuals, downregulation of CCR5 expression in anatomical compartments critical for establishment and propagation of HIV infection (i.e., genital and oropharyngeal mucosa, lymphoid tissue) might mimic the phenotype that results from mutation in the CCR5 gene. A similar phenotype might result from limited coreceptor availability caused by elevated levels of the ligands for CCR5, namely RANTES, MIP$1 \alpha$, and MIP-1 $\beta$. Although we found no difference in the serum levels of these $\beta$-chemokines in CCR5 wild-type versus heterozygous nonprogressors, a possibility currently under investigation in our laboratory is that important differences in levels of these chemokines may exist at the microenvironmental level where viral replication occurs (i.e., lymphoid tissue).

Another possible explanation for the failure of HIV-infected CCR5- $\Delta 32$ heterozygotes to constitute a distinct subgroup of nonprogressors could involve virologic factors. Michael et al. showed that any salutary role against disease progression played by CCR5- $\Delta 32$ was negated when CCR5- $\Delta 32$ heterozygotes harbored syncytium-inducing (SI) viruses which preferentially use CXCR4 rather than CCR5 as their coreceptor (33). Thus, the results of this study could be biased if there was skewing in the distribution of SI and NSI viruses such that CCR5- $\Delta 32$ heterozygotes preferentially harbored SI viruses. However, as we and others have reported previously, the number of HIV-infected long-term nonprogressors harboring SI viruses is negligible $(8,42)$, arguing against any skewing in the distribution of SI and NSI viruses between CCR5 wild-type and CCR5- $\Delta 32$ heterozygous nonprogressors.

Although our data support a role for the mutant CCR5 allele in the determination of the state of nonprogression in some HIV-infected individuals, other host and viral factors are also likely to be involved. The enormously complex interactions which occur between virus and host are obviously influ- enced by the products of the host's MHC genes. A number of epidemiologic studies have found a strong association between MHC haplotypes and rates of HIV-1 disease progression (4346). Genetic polymorphisms in host genes that are used by the virus for its own replication, or by the host in mounting an immune response against the virus, are also likely to play key roles in determining the rate of disease progression in infected individuals. The literature is replete with such examples in infectious, autoimmune, and neoplastic diseases (47-49). In this regard, a recent report describes an effect of variant alleles of mannose-binding lectin on susceptibility to HIV infection and disease progression (50). With regard to HIV-1 coreceptors, it is possible that polymorphisms in the CCR5 gene other than the 32-bp deletion may exist and play a role in determining the rate of disease progression. The same is true for polymorphisms in the CXCR4 (fusin) gene (51), the product of which functions as a coreceptor for SI strains of HIV-1 $(52,53)$. Genetic and regulatory features of CXCR4 expression as well as those of its natural ligand SDF-1 $(54,55)$ are currently under investigation in our laboratory as potential factors involved in long-term nonprogression with HIV-1 infection. Finally, many groups, including our own, continue to seek associations be-
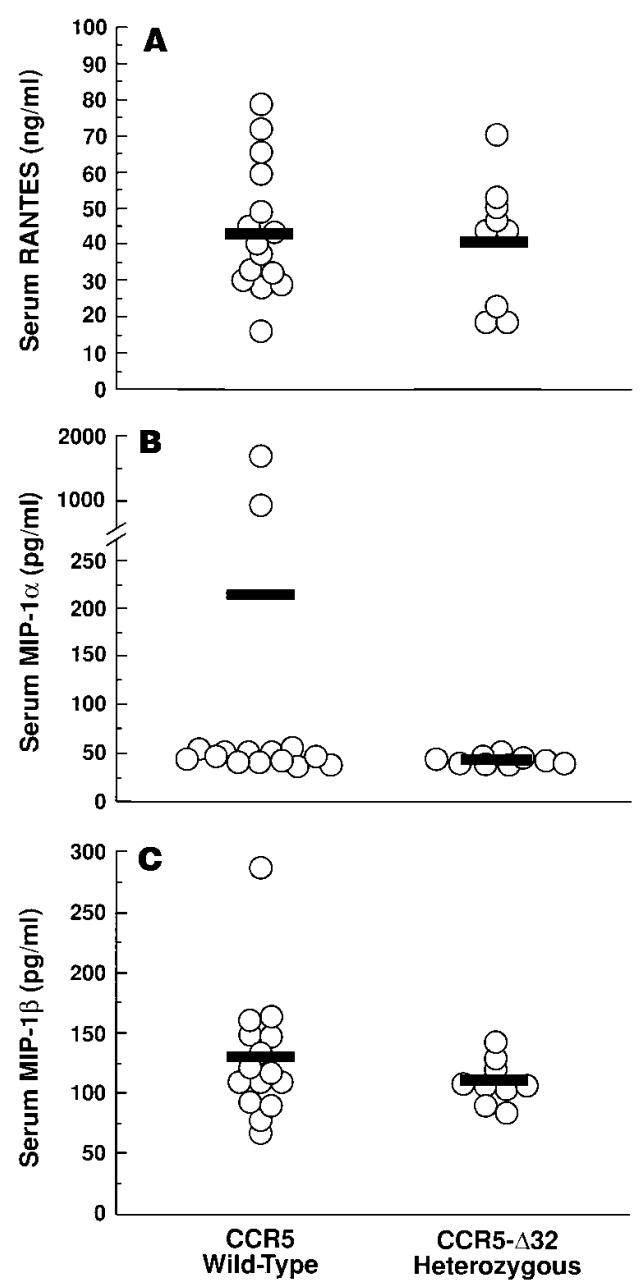

Figure 5. Comparative analysis of serum levels of the $\beta$-chemokines RANTES $(A), \operatorname{MIP}-1 \alpha(B)$, and MIP-1 $\beta(C)$ in CCR5 wild-type and CCR5- $\Delta 32$ heterozygous long-term nonprogressors. Mean values are indicated by horizontal bars. 
tween nonprogression and various quantitative and qualitative aspects of the humoral and cell-mediated immune responses against HIV-1 (6-8, 56-59).

In summary, although a disproportionately high frequency of CCR5- $\Delta 32$ heterozygotes was found among long-term nonprogressors, the hypothesis that this partial genetic defect might lead to lower viral loads and higher CD4+ T cell counts compared to CCR5 wild-type individuals could not be validated. Importantly, we measured viral load not only in the peripheral blood compartment, but also in lymphoid tissue, a critical reservoir and site of viral replication $(35,38,60,61)$. Despite our inability to distinguish CCR5 wild-type nonprogressors from CCR5- $\Delta 32$ heterozygous nonprogressors based on CD4+ T cell counts and several independent measures of viral load several years after primary infection, the mutant CCR5 allele still might play a role in nonprogression in HIV infection by limiting viral replication during acute infection and thus establishing a lower set point of viremia early on in the course of infection. Finally, this study fortifies the concept that HIV-infected long-term nonprogressors indeed represent a heterogeneous group with multiple host and viral factors likely to be responsible for their common phenotype of low viral loads and preserved immune function.

\section{Acknowledgments}

The authors gratefully acknowledge the clinical staff of the National Institute of Allergy and Infectious Diseases, the Surgery Branch of the National Cancer Institute, the San Francisco City Clinic, and the Multicenter AIDS Cohort Study for outstanding patient care, Dr. H. Clifford Lane for helpful discussion, Dr. Lewis K. Schrager and Dr. Janis V. Giorgi for assistance in patient recruitment, and Mary Rust for editorial assistance.

\section{References}

1. Fauci, A.S. 1993. Multifactorial nature of human immunodeficiency virus disease: implications for therapy. Science (Wash. DC). 262:1011-1018.

2. Fauci, A.S. 1996. Host factors and the pathogenesis of HIV-induced disease. Nature (Lond.). 384:529-534.

3. Lifson, A.R., S.P. Buchbinder, and H.W. Sheppard. 1991. Long-term human immunodeficiency virus infection in asymptomatic homosexual and bisexual men with normal CD4+ lymphocyte counts: immunologic and virologic characteristics. J. Infect. Dis. 163:959-965.

4. Sheppard, H.W., W. Lang, M.S. Ascher, E. Vittinghoff, and W. Winkelstein. 1993. The characterization of non-progressors: long-term HIV-1 infection with stable CD4+ T-cell levels. AIDS (Lond.). 7:1159-1166.

5. Easterbrook, P.J. 1994. Non-progression in HIV infection. AIDS (Lond.). 8:1179-1182.

6. Pantaleo, G., S. Menzo, M. Vaccarezza, C. Graziosi, O.J. Cohen, J.F. Demarest, D. Montefiori, J.M. Orenstein, C. Fox, L.K. Schrager, et al. 1995. Studies in subjects with long-term nonprogressive human immunodeficiency virus infection. N. Engl. J. Med. 332:209-216.

7. Cao, Y., L. Qin, L. Zhang, J. Safrit, and D.D. Ho. 1995. Virologic and immunologic characterization of long-term survivors of human immunodeficiency virus type 1 infection. N. Engl. J. Med. 332:201-208.

8. Montefiori, D., G. Pantaleo, L.M. Fink, J.T. Zhou, J.Y. Zhou, M. Bilska, G.D. Miralles, and A.S. Fauci. 1996. Neutralizing and infection-enhancing antibody responses to human immunodeficiency virus type 1 in long-term nonprogressors. J. Infect. Dis. 173:60-67.

9. Kirchhoff, F., T.C. Greenough, D.B. Brettler, J.L. Sullivan, and R.C. Desrosiers. 1995. Brief report: absence of intact nef sequences in a long-term survivor with nonprogressive HIV-1 infection. N. Engl. J. Med. 332:228-232.

10. Iversen, A.K.N., E.G., Shpaer, A.G. Rodrigo, M.S. Hirsch, B.D. Walker, H.W. Sheppard, T.C. Merigan, and J.I. Mullins. 1995. Persistence of attenuated rev genes in a human immunodeficiency virus type 1-infected asymptomatic individual. J. Virol. 69:5743-5753.

11. Deacon, N.J., A. Tsykin, A. Solomon, K. Smith, M. Ludford-Menting, D.J. Hooker, D.A. McPhee, A.L. Greenway, A. Ellett, C. Chatfield, et al. 1995. Genomic structure of an attenuated quasi species of HIV-1 from a blood trans- fusion donor and recipients. Science (Lond.). 270:988-991.

12. Huang, Y., L. Zhang, and D.D. Ho. 1995. Characterization of nef sequences in long-term survivors of human immunodeficiency virus type 1 infection. J. Virol. 69:93-100.

13. Nowak, M.A., R.M. May, R.E. Phillips, S. Rowland-Jones, D.G. Lalloo, S. McAdam, P. Klenerman, B. Köppe, K. Sigmund, C.R.M. Bangham, and A.J. McMichael. 1995. Antigenic oscillations and shifting immunodominance in HIV-1 infections. Nature (Lond.). 375:606-611.

14. Wolinsky, S., B.T.M. Korber, A.U. Neumann, M. Daniels, K.J. Kunstman, A.J. Whetsell, M.R. Furtado, Y. Cao, D.D. Ho, J.T. Safrit, and R.A. Koup. 1996. Adaptive evolution of human immunodeficiency virus type 1 during the natural course of infection. Science (Wash. DC). 272:537-542.

15. Deng, H., R. Liu, W. Ellmeier, S. Choe, D. Unutmaz, M. Burkhart, P. DiMarzio, S. Marmon, R.E. Sutton, C.M. Hill, et al. 1996. Identification of a major co-receptor for primary isolates of HIV-1. Nature (Lond.). 381:661-666.

16. Dragic, T., V. Litwin, G.P. Allaway, S.R. Martin, Y. Huang, K.A. Nagashima, C. Cayanan, P.J. Maddon, R.A. Koup, J.P. Moore, and W.A. Paxton. 1996. HIV-1 entry into CD4+ cells is mediated by the chemokine receptor CCCKR-5. Nature (Lond.). 381:667-673.

17. Alkhatib, G., C. Combadiere, C.C. Broder, Y. Feng, P.E. Kennedy, P.M. Murphy, and E.A. Berger. 1996. CC CKR5: a RANTES, MIP-1 $\alpha$, MIP-1 receptor as a fusion cofactor for macrophage-tropic HIV-1. Science (Wash DC). 272:1955-1958.

18. Choe, H., M. Farzan, Y. Sun, N. Sullivan, B. Rollins, P.D. Ponath, L. Wu, C.R. MacKay, G. LaRosa, W. Newman, et al. 1996. The $\beta$-chemokine receptors CCR3 and CCR5 facilitate infection by primary HIV-1 isolates. Cell. 85:1135-1148.

19. Doranz, B., J. Rucker, Y. Yi, R.J. Smyth, M. Samson, S.C. Peiper, M. Parmentier, R.G. Collman, and R.W. Doms. 1996. A dual-tropic primary HIV-1 isolate that uses fusin and the $\beta$-chemokine receptors CKR-5, CKR-3, and CKR-2b as fusion cofactors. Cell. 85:1149-1158.

20. Zhu, T., H. Mo, N. Wang, D.S. Nam, Y. Cao, R.A. Koup, and D.D. Ho. 1993. Genotypic and phenotypic characterization of HIV-1 in patients with primary infection. Science (Wash. DC). 261:1179-1181.

21. van't Wout, A.B., N.A. Kootstra, G.A. Mulder-Kampinga, N. Albrechtvan Lent, H.J. Scherpbier, J. Veenstra, K. Boer, R.A. Coutinho, F. Miedema, and H. Schuitemaker. 1994. Macrophage-tropic variants initiate human immunodeficiency virus type 1 infection after sexual, parenteral, and vertical transmission. J. Clin. Invest. 94:2060-2067.

22. Kinter, A.L., M. Ostrowski, D. Goletti, A. Oliva, D. Weissman, K. Gantt, E. Hardy, R. Jackson, L. Ehler, and A.S. Fauci. 1996. HIV replication in CD4 + T cells of HIV-infected individuals is regulated by a balance between the viral suppressive effects of endogenous beta-chemokines and the viral inductive effects of other endogenous cytokines. Proc. Natl. Acad. Sci. USA. 93:1407614081.

23. Cocchi, F., A.L. DeVico, A. Garzino-Demo, S.K. Arya, R.C. Gallo, and P. Lusso. 1995. Identification of RANTES, MIP-1 $\alpha$, and MIP-1 $\beta$ as the major HIV suppressive factors produced by CD8+ T cells. Science (Wash. DC). 270: 1811-1815.

24. Paxton, W.A., S.R. Martin, D. Tse, T.R. O'Brien, J. Skurnick, N.L. VanDevanter, N. Padian, J.F. Braun, D.P. Kotler, S.M. Wolinsky, and R.A Koup. 1996. Relative resistance to HIV-1 infection of CD4 lymphocytes from persons who remain uninfected despite multiple high-risk sexual exposures. Nat. Med. 2:412-417.

25. Liu, R., W.A. Paxton, S. Choe, D. Ceradini, S.R. Martin, R. Horuk, M.E. MacDonald, H. Stuhlmann, R.A. Koup, and N.R. Landau. 1996. Homozygous defect in HIV-1 coreceptor accounts for resistance of some multiplyexposed individuals to HIV-1 infection. Cell. 86:367-377.

26. Samson, M., F. Libert, B.J. Doranz, J. Rucker, C. Liesnard, C.M. Farber, S. Saragosti, C. Laouméroulie, J. Cognaux, C. Forceille, et al. 1996. Resistance to HIV-1 infection in caucasian individuals bearing mutant alleles of the CCR5 chemokine receptor gene. Nature (Lond.). 382:722-725.

27. Dean, M., M. Carrington, C. Winkler, G.A. Huttley, M.W. Smith, R. Allikmets, J.J. Goedert, S.P. Buchbinder, E. Vittinghoff, E. Gomperts, et al. 1996. Genetic restriction of HIV-1 infection and progression to AIDS by a deletion allele of the CKR5 structural gene. Hemophilia Growth and Development Study, Multicenter AIDS Cohort Study, Multicenter Hemophilia Cohort Study, San Francisco City Cohort, ALIVE Study. Science (Wash. DC). 273:1856-1862.

28. Huang, Y., W.A. Paxton, S.M. Wolinsky, A.U. Neumann, L. Zhang, T. He, S. Kang, D. Ceradini, Z. Jin, K. Yazdanbakhsh, et al. 1996. The role of a mutant CCR5 allele in HIV-1 transmission and disease progression. Nat. Med. 2:1240-1243.

29. Zimmerman, P.A., A. Buckler-White, G. Alkhatib, T. Spalding, J. Kubofcik, C. Combadiere, D. Weissman, O. Cohen, A. Rubbert, G. Lam, et al. 1997. Inherited resistance to HIV-1 conferred by an inactivating mutation in CC chemokine receptor 5: studies in populations with contrasting clinical phenotypes, defined racial backgrounds and quantified risks. Mol. Med. (Camb.). 3: 22-35.

30. Biti, R., R. French, J. Young, B. Bennetts, G. Stewart, and T. Liang. 1997. HIV-1 infection in an individual homozygous for the CCR5 deletion allele. Nat. Med. 3:252-253.

31. O'Brien, T.R., C. Winkler, M. Dean, J.A.E. Nelson, M. Carrington, N.L. 
Michael, and G.C. White. 1997. HIV-1 infection in a man homozygous for CCR5 32. Lancet. 349:1219.

32. Theodorou, I., L. Meyer, M. Magierowska, C. Katlama, and C. Rouzioux. 1997. HIV-1 infection in an individual homozygous for CCR5432. Lancet. 349: $1219-1220$.

33. Michael, N.L., G. Chang, L.G. Louie, J.R. Mascola, D. Dondero, D.L. Birx, and H.W. Sheppard. 1997. The role of viral phenotype and CCR5-5 gene defects in HIV-1 transmission and disease progression. Nat. Med. 3:338-340.

34. Eugen-Olsen, J., A.K.N. Iverson, P. Garred, U. Koppelhus, C. Pedersen, T.L. Benfield, and A.M. Sorenson. 1997. Heterozygosity for a deletion in the CKR-5 gene leads to prolonged AIDS-free survival and slower CD4 T-cell decline in a cohort of HIV-seropositive individuals. AIDS (Lond.). 11:305-310.

35. Pantaleo, G., C. Graziosi, L. Butini, P.A. Pizzo, S.M. Schnittman, D.P. Kotler, and A.S. Fauci. 1991. Lymphoid organs function as major reservoirs for human immunodeficiency virus. Proc. Natl. Acad. Sci. USA. 88:9838-9842.

36. Cohen, O.J., G. Pantaleo, M. Holodniy, S. Schnittman, M. Niu, C. Graziosi, G.N. Pavlakis, J. Lalezari, J.A. Bartlett, R.T. Steigbigel, et al. 1995. Decreased HIV-1 plasma viremia during antiretroviral therapy reflects downregulation of viral replication in lymphoid tissue. Proc. Natl. Acad. Sci. USA. 92:6017-6021.

37. Neumann, M., J. Harrison, M. Saltarelli, E. Hadziyannis, V. Erfle, B.K. Felber, and G.N. Pavlakis. 1994. Splicing variability in HIV type 1 revealed by quantitative RNA polymerase chain reaction. AIDS Res. Hum. Retroviruses. 10:1531-1542.

38. Fox, C.H., K. Tenner-Rácz, P. Rácz, A. Firpo, P.A. Pizzo, and A.S. Fauci. 1991. Lymphoid germinal centers are reservoirs of human immunodeficiency virus type 1 RNA. J. Infect. Dis. 164:1051-1057.

39. Wu, L. W.A. Paxton, N. Kassam, N. Ruffing, J.B. Rottman, N. Sullivan, H. Choe, J. Sodroski, W. Newman, R.A. Koup, and C.R. Mackay. 1997. CCR5 levels and expression pattern correlate with infectability by macrophage-tropic HIV-1, in vitro. J. Exp. Med. 185:1681-1692.

40. Mellors, J.W., L.A. Kingsley, C.R. Rinaldo, Jr., J.A. Todd, B.S. Hoo, R.P. Kokka, and P. Gupta. 1995. Quantitation of HIV-1 RNA in plasma predicts outcome after seroconversion. Ann. Intern. Med. 122:573-579.

41. Schacker, T., A.C. Collier, J. Hughes, T. Shea, and L. Corey. 1996. Clinical and epidemiologic features of primary HIV infection. Ann. Intern. Med. $125: 257-264$

42. Balotta, C., P. Bagnarelli, C. Riva, A. Valenza, S. Antinori, M.C. Colombo, R. Sampaolesi, M. Violin, M.P. De Pasquale, M. Moroni, et al. 1997. Comparable biological and molecular determinants in HIV type 1-infected long term nonprogressors and recently infected individuals. AIDS Res. Hum. Retroviruses. 13:337-341.

43. Kaslow, R.A., R. Duquesnoy, M. VanRaden, L. Kingsley, M. Marrari, H. Friedman, S. Su, A.J. Saah, R. Detels, J. Phair, and C. Rinaldo. 1990. A1, Cw7, B8, DR3 HLA antigen combination associated with rapid decline of T-helper lymphocytes in HIV-1 infection. Lancet. 335:927-930.

44. Klein, M.R., I.P.M. Keet, J. D'Amaro, R.J. Bende, A. Hekman, B. Mesman, M. Koot, L.P. de Waal, R.A. Coutinho, and F. Miedema. 1994. Associations between HLA frequencies and pathogenic features of human immunodeficiency virus type 1 infection in seroconverters from the Amsterdam cohort of homosexual men. J. Infect. Dis. 169:1244-1249.

45. Kroner, B.L., J.J. Goedert, M. Carrington, D.L. Mann, and W.A. Blattner. 1995. Concordance of haplotype sharing, CD4 decline, and AIDS in hemophilic sibling pairs. AIDS. 9:275-280.

46. Kaslow, R.A., M. Carrington, R. Apple, L. Park, A. Muñoz, A.J. Saah,
J.J. Goedert, C. Winkler, S.J. O'Brien, C. Rinaldo, et al. 1996. Influence of combinations of human major histocompatibility complex genes on the course of HIV-1 infection. Nat. Med. 2:405-411.

47. Weatherall, D.J. 1996. Host genetics and infectious disease. Parasitology. 112:S23-S29.

48. Winchester, R. 1994. The molecular basis of susceptibility to rheumatoid arthritis. Adv. Immunol. 56:389-466.

49. Smith, G., L.A. Stanley, E. Sim, R.C. Strange, and C.R. Wolf. 1995. Metabolic polymorphisms and cancer susceptibility. Cancer Surv. 25:27-65.

50. Garred, P., H.O. Madsen, U. Balslev, B. Hofmann, C. Pedersen, J. Gerstoft, and A. Svejgaard. 1997. Susceptibility to HIV infection and progression of AIDS in relation to variant alleles of mannose-binding lectin. Lancet. 349: 236-240.

51. Loetscher, M., T. Geiser, T. O'Reilly, R. Zwahlen, M. Baggiolini, and B. Moser. 1994. Cloning of a human seven-transmembrane domain receptor, LESTR, that is highly expressed in leukocytes. J. Biol. Chem. 269:232-237.

52. Feng, Y., C.C. Broder, P.E. Kennedy, and E.A. Berger. 1996. HIV-1 entry cofactor: functional cDNA cloning of a seven-transmembrane domain, G-protein coupled receptor. Science (Wash. DC). 272:872-877.

53. Berson, J.F., D. Long, B.J. Doranz, J. Rucker, F.R. Jirik, and R.W. Doms. 1996. A seven-transmembrane domain receptor involved in fusion and entry of T-cell-tropic human immunodeficiency virus type 1 strains. $J$ Virol. 70: 6288-6295.

54. Bleul, C., M. Farazan, H. Choe, C. Parolin, I. Clark-Lewis, J. Sodroski, and T.A. Springer. 1996. The lymphocyte chemoattractant SDF-1 is a ligand for LESTR/fusin and blocks HIV-1 entry. Nature (Lond.). 382:829-833.

55. Oberlin, E., A. Amara, F. Bachelerie, C. Bessia, J.L. Virelizier, F. Arenzana-Seisdedos, O. Schwartz, J.M. Heard, I. Clark-Lewis, D.F. Legler, et al. 1996. The CXC chemokine SDF-1 is the ligand for LESTR/fusin and prevents infection by T-cell-line-adapted HIV-1. Nature (Lond.). 382:833-835.

56. Harrer, T., E. Harrer, S.A. Kalams, P. Barbosa, A. Trocha, R.P. Johnson, T. Elbeik, M.B. Feinberg, S.P. Buchbinder, and B.D. Walker. 1996. Cytotoxic T lymphocytes in asymptomatic long-term nonprogressing HIV-1 infection. Breadth and specificity of the response and relation to in vivo viral quasispecies in a person with prolonged infection and low viral load. J. Immunol. 156:26162623.

57. Barker, T.D., D. Weissman, J.A. Daucher, K.M. Roche, and A.S. Fauci. 1996. Identification of multiple and distinct CD8+ T cell suppressor activities. J. Immunol. 156:4476-4483.

58. Moriuchi, H., M. Moriuchi, C. Combadiere, P.M. Murphy, and A.S. Fauci. 1996. CD8 $+\mathrm{T}$ cell derived soluble factor(s), but not $\beta$-chemokines RANTES, MIP- $1 \alpha$, and MIP-1 $\beta$, suppress HIV-1 replication in monocyte/macrophages. Proc. Natl. Acad. Sci. USA. 93:15341-15345.

59. Pilgrim, A.K., G. Pantaleo, O.J. Cohen, L.M. Fink, J.Y. Zhou, J.T. Zhou, D.P. Bolognesi, A.S. Fauci, and D.C. Montefiori. 1997. Neutralizing antibody responses at various stages of infection with human immunodeficiency virus type 1 . J. Infect. Dis. In press.

60. Pantaleo, G., C. Graziosi, J.F. Demarest, L. Butini, M. Montroni, C.H. Fox, J.M. Orenstein, D.P. Kotler, and A.S. Fauci. 1993. HIV infection is active and progressive in lymphoid tissue during the clinically latent stage of disease. Nature (Lond.). 362:355-358.

61. Embretson, J., M. Zupancic, J.L. Ribas, A. Burke, P. Rácz, K. TennerRácz, and A.T. Haase. 1993. Massive covert infection of helper T lymphocytes and macrophages by HIV during the incubation period of AIDS. Nature (Lond.). 362:359-362. 